S. Tikhlivets, PhD (Geol.), Associate. prof. E-mail: tikhlivets.svetlana@gmail.com; Kryvyi Rih National University, 37 Pushkina Str., Kryvyi Rih, 50002, Ukraine

\title{
VARIABILITY OF PHYSICAL AND CHEMICAL PROPERTIES OF MAGNETITE AND QUARTZ OF THE NORTHERN DESTRICT OF KRYVYI RIH BASIN
}

(Представлено членом редакційної колегії д-ром геол. наук, доц. С.Є. Шнюковим)

Physical properties of minerals represent a function of their chemical composition, features of morphology and anatomy. Their variability is influenced by geological syngenetic and epigenetic processes that occur within the iron ore deposits of Kryvyi Rih basin. The latter is represented by nine deposits, which are exploited by five ore mining and enrichment works (GZKs). The Northern region of Kryvyi Rih basin includes Hannivske and Pervomayske deposits. The productive strata of both deposits consist of low-grade magnetite ores of the fifth and sixth ferruginous horizons. They are characterized by the authigenic-metamorphogenic mineralogical zonation.

The purpose of the work is conditioned by the need for a detailed study of the laws of variability of chemical composition and physical properties of rock-forming minerals (magnetite and quartz), taking into account their position within zonal ore deposits.

The study of the physical properties of rock-forming minerals was carried out according to standard methods using a microhardness tester, the chemical composition was investigated by segregating monomineral fractions of magnetite and quartz from ores of metamorphic or metasomatic origins of various mineral composition using a magnetic separator. The chemical analyzes were carried out in a standardized chemical laboratory. Statistical studies were performed using Excel software and Corel Draw.

Result of the researches showed the nature of variability of the chemical composition, physical properties of magnetite and quartz in the sections of metamorphogenic and metasomatically altered ore strata of iron ore deposits.

Practical significance is conditioned by the necessity of conducting detailed topomineralogical study of the productive strata of iron ore deposits of Kryvyi Rih basin in relation to the work on updating the mineralogical and technological map of the deposit, compiling an optimal scheme for ore blending in order to increase efficiency of the use of natural technological potential of magnetite quartzites on the basis of studying physical and chemical properties of the main rock-forming minerals of ferruginous quartzite.

Keywords: Ukrainian Shield, banded-iron formation, Kryvyi Rih basin, ferruginous quartzites, magnetite, quartz.

Challenge problem. The Northern region of Kryvyi Rih basin is represented by two deposits - Hannivka and Pervomaiske, which are exploited by similary named openpits of the Northern Ore Mining and Beneficiating Works (PivnGZK) (Glazunov, 2009). Productive strata of these deposits are composed of low-grade magnetite quartzites of the fifth and sixth ferruginous horizons.

Syngenetic processes occurrence has caused the forming of an authentically metamorphogenic mineralogical zonation within the productive strata of Hannivka and Pervomayske deposits (Belevtsev, 1970; Chubarov and Evtekhov, 1996), where it is manifested the most fully. Generally, in the sections of the fifth and sixth horizons in the direction from the hanging and foot walls to their central zones, there is a natural change in the layers represented by ferruginous quartzite of the following mineral composition: magnetite-cummingtonite quartzites $\rightarrow$ cummingtonitemagnetite quartzites $\rightarrow$ magnetite quartzites $\rightarrow$ micaceous hematite-magnetite quartzites (Evtekhov, 2009; Karpenko, 2008). In the sections of the sixth ferruginous horizon, the latter are relatively thin or absent.

Ores of the deposits have also undergone epigenetic processes (Paranko, 1997), which influenced the qualitative parameters of magnetite quartzites such as: tectonogenesis, sodium metasomatosis, hypergenesis (Tikhlivets, 2017), and others. The influence of these processes has led to the formation of a modern topomineralogical variability of the productive strata of both Hannivka and Pervomaiske deposits. Based on the above, the author decided to conduct research within the productive strata of Hannivka deposit.

In accordance with the mineralogical zoning of iron ore deposits, there is not only a natural change in the content of ore-forming, secondary and accessory minerals in ferruginous quartzites, but also a variability of the chemical composition and physical properties of the minerals. The latter determines the versatility of technological parameters of the ferruginous quartzites, which needs a detailed study of the properties of rock-forming minerals.

Research analysis. The issue of dependence of the chemical and physical characteristics of minerals on the mineral composition of ferruginous quartzites, their position in the sections of deposits was studied by many preceding researchers (Belevtzev, 1970; Bespoyasko, 2004; Evtekhov and Dotsenko, 1979; Prušinskienè, 2017; Rakovich, 1983; Tikhlivets, 2017). The authors concluded that there are general patterns of variation of most parameters in sections of ore deposits of different genesis.

The physical, chemical and technological parameters of the ores of the deposit were studied in the 50s-70s of the 20th century in connection with the design and start of work of the Northern Ore Mining and Beneficiating Works. The tests were carried out in the course of preliminary, detailed, operational exploration of Hannivka and Pervomaiske deposits, in connection with the implementation of research works (Evtekhov and Dotsenko, 1979). The questions of research analysis about sodium metasomatites of the Pervomaiske deposit are disclosed in Tikhlivets's work (Tikhlivets and Filenko, 2017). The variability of morphological characteristics of ore minerals, taking into account their position within zonal ore deposits, is shown in work (Tikhlivets, 2019). In this work, the author reveals the need to study the physical and chemical properties of main ore minerals, depending on their location in the productive strata of the deposit.

Objective of the research consisted in a more detailed determining of the laws of variability of minerals chemical composition, taking into account their position within zonal ore deposits. The main attention was paid to studying the laws of change in the chemical composition and physical properties of the main ore-forming minerals in the zones of ferruginous horizons and bodies of sodium metasomatites of the productive strata of Hannivka deposit. The microhardess of magnetite and quarts was taken as the main characteristic of the physical properties of rock-forming minerals.

The purpose of the research conducted is due to the need for continuous monitoring of mineral composition, structure, texture of ores and, as a consequence, physical properties and chemical composition of the main rock-forming minerals of ferruginous quartzite for further improvement of the technological parameters of iron concentrate.

Research methodology. In the process of studying the physical properties of magnetite and quartz, standard techniques were used. Determining of microhardness was carried out using a microhardness tester MP-1. 200-300

(c) Tikhlivets S., 2021 
measurements were performed for magnetite and quartz from each zone.

To perform a detailed study of the chemical composition of magnetite the author identified its 87 monomineral fractions from ores of metamorphic and metasomatic origin. The samples represented all the mineralogical zones of the ore deposits of both genetic varieties. The content determining of chemical components in the magnetite was conducted using the method of complete silicate chemical analysis in the laboratories of PivnGZK and Kryvyi Rih integrated geological party. To study the content of chemical components in quartz, its monomineral fractions were used, which served for conducting semiquantitative spectral analyzes. The latter were carried out in the chemical laboratory of Kryvyi Rih integrated party.

Laying out the main material. Physical properties of minerals represent the function of their chemical composition, the structure of the crystalline lattice, the features of morphology and anatomy (Pavlyshyn et al, 2003; Bespoyasko, 2004; Matkovskyi et al., 2006; Tikhlivets and Filenko, 2018). The close connection between these properties of the minerals of the banded-iron formation was mentioned in the previous works (Evtekhov, 1992;
Pavlyshyn, 1984). In the works of V.D. Evtekhov (Evtekhov, 1992) the data concerning connection of physical properties of the minerals with their positions in the sections of iron ores bodies of various deposits of Kryvyi Rih basin of different origins (metamorphites, metasomatites) were given.

Microhardness is one of physical properties of minerals. The author of this article investigated the character of the variability of this indicator in magnetite and quartz for the sections of the ferruginous horizons and bodies of sodium metasomatites. Samples of sodium metasomatites were selected from layers of micaceous hematite-magnetite and magnetite quartzites. The metasomatic bodies of the central zones of the ferruginous horizons, represented by ferruginous quartzite of this composition, are characterized by the most complete and clear manifestations of metasomatic zonation. The latter is represented by the following zones: the aegirinization zone (central), the zone of riebeckitization (intermediate), the zone of silicification (peripheral zone) (Tikhlivets and Filenko, 2017).

The nature of the variability of the hardness of magnetite in the zones of stratigraphic horizons and metasomatic bodies is shown in the Table 1-2.

The hardness of magnetite from unaltered ferruginous quartzites of the productive strata of Hannivka deposit

\begin{tabular}{|c|c|c|c|c|}
\hline \multirow{2}{*}{ № } & \multirow{2}{*}{ Mineral varieties of ferruginous quartzites } & \multicolumn{3}{|c|}{ The hardness $\mathrm{H}_{\mathrm{v}}, \mathrm{MPa}$} \\
\hline & & $\mathbf{n}$ & $\mathbf{x}$ & $\mathbf{S}_{\mathbf{x}}$ \\
\hline 1 & Micaceous-hematite-magnetite quartzites & 18 & 5236 & 738 \\
\hline 2 & Magnetite quartzites & 16 & 5147 & 751 \\
\hline 3 & Cummingtonite-magnetite quartzites & 17 & 5123 & 763 \\
\hline 4 & Magnetite-cummingtonite quartzites & 15 & 5014 & 782 \\
\hline
\end{tabular}

Note: $n$ - number of definitions; $x$ is the average value of the indicators; Sx - standard deviation.

The hardness of magnetite from sodium metasomatites of the productive strata of Hannivka deposit

Table 2

\begin{tabular}{|c|c|c|c|c|}
\hline \multirow{2}{*}{ № } & \multirow{2}{*}{ Mineral varieties of metasomatites, which were formed in } & \multicolumn{3}{|c|}{ The hardness $\mathrm{H}_{\mathrm{v}}, \mathrm{MPa}$} \\
\hline & & $\mathbf{n}$ & $\mathbf{x}$ & $\mathbf{S}_{\mathbf{x}}$ \\
\hline \multicolumn{5}{|c|}{ micaceous-hematite-magnetite quartzites } \\
\hline 1 & Riebeckite- magnetite-aegirine metasomatites & 25 & 5146 & 805 \\
\hline 2 & Micaceous-hematite-riebeckite-magnetite quartzites & 23 & 5421 & 776 \\
\hline 3 & Micaceous-hematite-magnetite quartzites silificate & 15 & 5523 & 798 \\
\hline \multicolumn{5}{|c|}{ magnetite quartzites } \\
\hline 4 & Riebeckite- magnetite-aegirine metasomatites & 25 & 5146 & 805 \\
\hline 5 & Riebeckite-magnetite quartzites & 17 & 5396 & 717 \\
\hline 6 & Magnetite quartzites silificate & 16 & 5425 & 825 \\
\hline
\end{tabular}

Note: $n$ - number of definitions; $x$ is the average value of the indicators; Sx - standard deviation.

The magnetite hardness (Fig. 1, a) naturally and gradually decreases from the central zones of the ferruginous horizons, composed of micaceous hematitemagnetite quartzite, to the peripheral ones, composed of magnetite-cummingtonite quartzites. In the same direction, the value of the mean square deviation of this indicator is gradually increasing. The latter can be explained by an increase in the variability of the chemical composition of magnetite. The decrease of the mean values of microhardness might be due to the decrease in hematite minals in it $\left(\mathrm{Fe}_{2} \mathrm{O}_{3}\right.$ content), which is characterized by higher microhardness (Evtekhov and Dotsenko, 1979).

The hardness of magnetite in the zones of the bodies of sodium metasomatites (Fig. 1, b) also varies. From the central zones of aegirinization to the peripheral zones of silicification of ferruginous quartzites, the value of this indicator is gradually increasing. According to the author, this can be explained by recrystallization, improvement in the process of metasomatic changes in the internal structure of individuals of magnetite. The regularities of the change in the mean square deviation of hardness have not been detected.
In a detailed study of chemical composition of magnetite, which was determined by the method described above, the results of chemical analyzes of metamorphogenic magnetite (Table 3, Fig. 2) and then of magnetite from metasomatic zones (Table 4, Fig. 3) were the first to be analyzed. Chemical analyzes were carried out for quartzites from each zone of autigenic-metamorphogenic (micaceous hematitemagnetite, magnetite, cummingtonite-magnetite, magnetitecummingtonite) and metasomatic (zones of aegirinization, riebeckitization and silicification) zoning.

The chemical composition of metamorphogenic (magnetite, quartz, cummingtonite etc.) and metasomatic (aegirine, riebeckite, albite, etc.) minerals, according to previous researchers (Prušinskiené et al., 2017; Belik, 1984; Evtekhov, 1992; Karpenko and Evtekhov, 2006), is characterized by considerable variability both within the productive strata and in the iron ore deposits as a whole. The obove-mentioned authors emphasized the dependence of the chemical composition of minerals on the composition of the enclosing rocks, the thermodynamic conditions of their metasomatic transformations, weathering, and the like. 


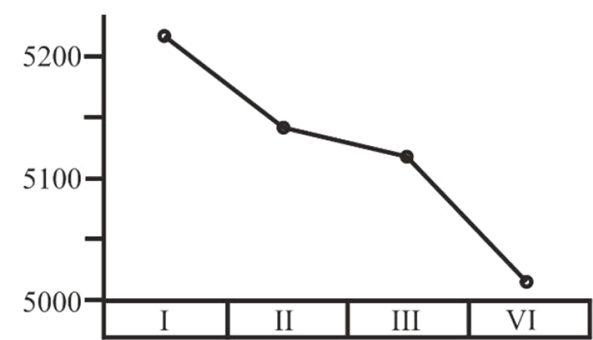

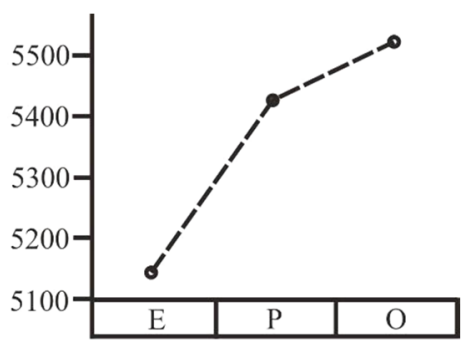

b

Fig. 1. Variability of the hardness of magnetite from productive strata of deposit:

$a$ - magnetite from unaltered ferruginous quartzites; $b$ - magnetite from sodium metasomatites; 5000-5500 - average value of the hardness.

Mineral varieties of ferruginous quartzites: I - micaceous-hematite-magnetite quartzites; II - magnetite quartzites;

III - cummingtonite-magnetite quartzites; VI - magnetite-cummingtonite quartzites.

Zone of sodium metasomatites: $\mathrm{E}$ - aegirinization, $\mathrm{P}$ - riebeckitization; $\mathrm{O}$ - silicification

Table 3

Chemical composition (mas. \%) magnetite from unaltered ferruginous quartzites of the productive strata

\begin{tabular}{|c|c|c|c|c|}
\hline \multirow[b]{2}{*}{ Chemical components } & \multicolumn{4}{|c|}{ Mineral varieties of ferruginous quartzites } \\
\hline & $\begin{array}{l}\text { micaceous-hematite- } \\
\text { magnetite quartzites }\end{array}$ & magnetite quartzites & $\begin{array}{c}\text { cummingtonite- } \\
\text { magnetite quartzites }\end{array}$ & $\begin{array}{c}\text { magnetite- } \\
\text { cummingtonite } \\
\text { quartzites }\end{array}$ \\
\hline $\mathrm{SiO}_{2}$ & 0,87 & 1,15 & 1,19 & 1,26 \\
\hline $\mathrm{TiO}_{2}$ & 0,013 & 0,013 & 0,015 & 0,017 \\
\hline $\mathrm{Al}_{2} \mathrm{O}_{3}$ & 0,06 & 0,08 & 0,10 & 0,19 \\
\hline $\mathrm{Fe}_{2} \mathrm{O}_{3}$ & 69,23 & 68,35 & 67,57 & 66,97 \\
\hline $\mathrm{FeO}$ & 29,53 & 29,91 & 29,98 & 30,11 \\
\hline $\mathrm{MnO}$ & 0,011 & 0,013 & 0,015 & 0,019 \\
\hline $\mathrm{MgO}$ & 0,16 & 0,22 & 0,66 & 0,88 \\
\hline $\mathrm{CaO}$ & 0,08 & 0,16 & 0,19 & 0,26 \\
\hline $\mathrm{Na}_{2} \mathrm{O}$ & 0,01 & 0,00 & 0,00 & 0,00 \\
\hline $\mathrm{K}_{2} \mathrm{O}$ & 0,00 & 0,00 & 0,00 & 0,00 \\
\hline $\mathrm{P}_{2} \mathrm{O}_{5}$ & 0,00 & 0,00 & 0,00 & 0,00 \\
\hline $\mathrm{CO}_{2}$ & 0,01 & 0,02 & 0,03 & 0,05 \\
\hline $\mathrm{S}$ & 0,00 & 0,00 & 0,00 & 0,00 \\
\hline $\mathrm{H}_{2} \mathrm{O}^{+}$ & 0,00 & 0,00 & 0,00 & 0,00 \\
\hline $\mathrm{H}_{2} \mathrm{O}^{-}$ & 0,01 & 0,03 & 0,04 & 0,06 \\
\hline Total & 99,984 & 99,946 & 99,671 & 99,789 \\
\hline Quantity of determinations & 10 & 13 & 10 & 14 \\
\hline
\end{tabular}

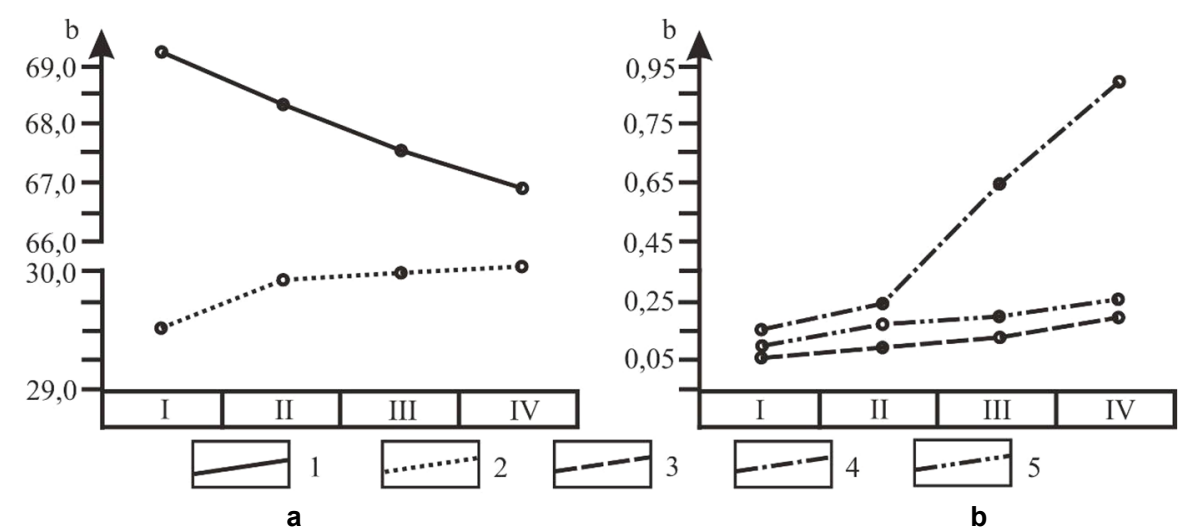

Fig. 2. Variability of ferruginous (a) and aluminum (b) chemical components of magnetite from mineral varieties of ferruginous quartzites of the productive strata.

$1-\mathrm{Fe}_{2} \mathrm{O}_{3} ; 2-\mathrm{FeO}, 3-\mathrm{Al}_{2} \mathrm{O}_{3} ; 4-\mathrm{MgO} ; 5-\mathrm{CaO} . b$-intermedial content of components. Mineral varieties of ferruginous quartzites: see Fig. 1

According to the data obtained, it is evident that the chemical composition of magnetite in the central zones of the fifth and sixth ferruginous horizons is close to stoichiometric one, which confirms the data of the previous researchers (Rakovych, 1983). In the direction towards peripheral zones there is a significant redistribution of iron between $\mathrm{Fe}_{2} \mathrm{O}_{3}$ and $\mathrm{FeO}$. The increase in the content of the latter against the reduction of the content of oxidized iron, may be explained by a gradual decrease in the oxygen fugacity in metamorphogenic solutions with the approaching to the contact zones of the ferruginous horizons. The growth of $\mathrm{Al}_{2} \mathrm{O}_{3}, \mathrm{MnO}, \mathrm{MgO}, \mathrm{CaO}$ in this direction has also been observed, which can be explained by the isomorphic inclusion of these components into the crystalline lattice of magnetite due to their high quantity in the enclosing cummingtonite-magnetite and magnetite-cummingtonite quartzites. $\mathrm{SiO}_{2}$ is present in the monomineral fractions of magnetite as a mechanical impurity.

Sodium metasomatosis also greatly affected the chemical composition of magnetite. In the Table 4, the results of chemical analysis in metasomatic zones formed by micaceous hematitemagnetite and magnetite quartzites are presented. 
Table 4

Chemical composition (mas.\%) magnetite from sodium metasomatites of the productive strata

\begin{tabular}{|c|c|c|c|c|c|c|}
\hline \multirow[t]{2}{*}{ Chemical components } & \multicolumn{3}{|c|}{$\begin{array}{c}\text { metasomatites, which were formed } \\
\text { in micaceous-hematite-magnetite quartzites }\end{array}$} & \multicolumn{3}{|c|}{$\begin{array}{c}\text { metasomatites, which were formed } \\
\text { in magnetite quartzites }\end{array}$} \\
\hline & 1 & 2 & 3 & 1 & 2 & 3 \\
\hline $\mathrm{SiO}_{2}$ & 0,83 & 0,89 & 0,95 & 0,89 & 1,08 & 1,19 \\
\hline $\mathrm{TiO}_{2}$ & 0,00 & 0,014 & 0,012 & 0,00 & 0,019 & 0,007 \\
\hline $\mathrm{Al}_{2} \mathrm{O}_{3}$ & 0,21 & 0,18 & 0,10 & 0,21 & 0,14 & 0,15 \\
\hline $\mathrm{Fe}_{2} \mathrm{O}_{3}$ & 69,07 & 68,49 & 68,54 & 68,94 & 68,49 & 67,85 \\
\hline $\mathrm{FeO}$ & 29,81 & 30,05 & 30,14 & 29,81 & 30,15 & 29,79 \\
\hline $\mathrm{MnO}$ & 0,008 & 0,016 & 0,014 & 0,008 & 0,013 & 0,015 \\
\hline $\mathrm{MgO}$ & 0,27 & 0,13 & 0,17 & 0,27 & 0,21 & 0,23 \\
\hline $\mathrm{CaO}$ & 0,11 & 0,05 & 0,14 & 0,11 & 0,13 & 0,16 \\
\hline $\mathrm{Na}_{2} \mathrm{O}$ & 0,05 & 0,01 & 0,01 & 0,05 & 0,04 & 0,01 \\
\hline $\mathrm{K}_{2} \mathrm{O}$ & 0,01 & 0,00 & 0,01 & 0,01 & 0,01 & 0,01 \\
\hline $\mathrm{P}_{2} \mathrm{O}_{5}$ & 0,00 & 0,00 & 0,00 & 0,00 & 0,00 & 0,00 \\
\hline $\mathrm{CO}_{2}$ & 0,01 & 0,01 & 0,02 & 0,01 & 0,01 & 0,01 \\
\hline $\mathrm{S}$ & 0,00 & 0,00 & 0,00 & 0,00 & 0,00 & 0,00 \\
\hline $\mathrm{H}_{2} \mathrm{O}^{+}$ & 0,01 & 0,01 & 0,01 & 0,01 & 0,01 & 0,00 \\
\hline $\mathrm{H}_{2} \mathrm{O}^{-}$ & 0,03 & 0,03 & 0,02 & 0,03 & 0,03 & 0,03 \\
\hline Total & 99,868 & 100,46 & 100,136 & 99,898 & 100,782 & 99,452 \\
\hline Quantity of determinations & 6 & 10 & 4 & 6 & 11 & 6 \\
\hline
\end{tabular}

Note: zone of sodium metasomatites: 1 - aegirinization, 2 - riebeckitization; 3 - silicification.

The analysis of the data shows that the composition of the magnetite, which had undergone metasomatic transformations, had an influence on the composition of the enclosing rocks, as well as the composition of metasomatizing solutions. The influence of the content of the enclosing rocks is noticeable when comparing the contents of $\mathrm{Al}_{2} \mathrm{O}_{3}, \mathrm{MgO}, \mathrm{MnO}, \mathrm{CaO}, \mathrm{K}_{2} \mathrm{O}$ in magnetite from metasomatically altered micaceous hematite-magnetite and magnetite quartzites. Higher content of these components is observed for magnetite from sodium metasomatites in magnetite quartzites. The higher content of these components is typical for magnetite from the latter ones.

For magnetite from the zones of aegirinization high content of chemical components, which were carried by metasomatizing solutions $-\mathrm{Al}_{2} \mathrm{O}_{3}, \mathrm{MgO}$, is typical. Reducing the fugacity of oxygen in the metamorphosed solutions in the direction from the central to the peripheral zones of the metasomatic bodies caused an increase in the content of $\mathrm{FeO}$ in the magnetite in this direction.

Quartz is another rock-forming mineral in ferruginous quartzites of the productive strata of Hannivka deposit. The results the microhardness of quartz measuring in various mineralogical zones of the productive strata of the deposit are given in the Tables 5 and 6 . Microhardness of quartz in the direction from the central zone of the productive strata to the peripheral ones revealed its decrease (Fig. 3, a). This is likely to be explained by an increase in the number of gasliquid inclusions in quartz individuals in this direction. At the same time, the mean square deviation of the microhardness of quartz is also decreasing, which indicates an increase in homogeneity of its individuals after anatomical and micromorphological indexes.

Tables 5

The hardness of quartz from unaltered ferruginous quartzites of the productive strata of Hannivka deposit

\begin{tabular}{|c|c|c|c|c|}
\hline \multirow{2}{*}{ № } & \multirow{2}{*}{ Mineral varieties of ferruginous quartzites } & \multicolumn{3}{|c|}{ Hardness $\mathrm{H}_{\mathrm{v}}, \mathrm{MPa}$} \\
\hline & & $\mathbf{n}$ & $\mathbf{x}$ & $\mathbf{S}_{\mathrm{x}}$ \\
\hline 1 & Micaceous-hematite-magnetite quartzites & 30 & 11798 & 867 \\
\hline 2 & Magnetite quartzites & 17 & 11627 & 764 \\
\hline 3 & Cummingtonite-magnetite quartzites & 12 & 11578 & 745 \\
\hline 4 & Magnetite-cummingtonite quartzites & 15 & 11436 & 698 \\
\hline
\end{tabular}

Table 6

The hardness of quartz from sodium metasomatites of the productive strata of Hannivka deposit

\begin{tabular}{|c|c|c|c|c|}
\hline \multirow{2}{*}{ № } & \multirow{2}{*}{ Mineral varieties of metasomatites, which were formed in } & \multicolumn{3}{|c|}{ Hardness $\mathrm{H}_{\mathrm{v}}, \mathrm{MPa}$} \\
\hline & & $\mathbf{n}$ & $\mathbf{x}$ & $\mathbf{S}_{\mathrm{x}}$ \\
\hline \multicolumn{5}{|c|}{ micaceous-hematite-magnetite quartzites } \\
\hline 1 & Riebeckite- magnetite-aegirine metasomatites & 20 & 10846 & 945 \\
\hline 2 & Micaceous-hematite-riebeckite-magnetite quartzites & 25 & 11978 & 736 \\
\hline 3 & Micaceous-hematite-magnetite quartzites silificate & 23 & 11904 & 827 \\
\hline \multicolumn{5}{|c|}{ magnetite quartzites } \\
\hline 4 & Riebeckite- magnetite-aegirine metasomatites & 20 & 10846 & 945 \\
\hline 5 & Riebeckite-magnetite quartzites & 21 & 11996 & 699 \\
\hline 6 & Magnetite quartzites silificate & 25 & 11644 & 920 \\
\hline
\end{tabular}

Note: $n$ - number of determinations (analysed samples); $x$ is the average value of the indicators; $S x$ - standard deviation.

The quartz from sodium metasomatites (Fig. 3, b) is characterized by maximum hardness for the areas of riebeckitization. In one of previous works (Tikhlivets, 2019) the author mentioned that crystals of quartz of this zone are more perfect in comparison with crystals of other zones in terms of micromorphological and anatomical parameters. The minimum hardness is characteristic of quartz from the zones of aegirinization.
Regarding the chemical composition, quartz is characterized by an extreme stability. Structural impurities in its crystalline lattice are present in the amount that does not exceed $0.001-0.1$ mass \%. It is also noted that numerous and varied solids and liquid-gas constituents are present in quartz, which largely determines the presence and content of the impurity elements in its composition. The very presence of these inclusions affects the physical properties of quartz, as described above. 

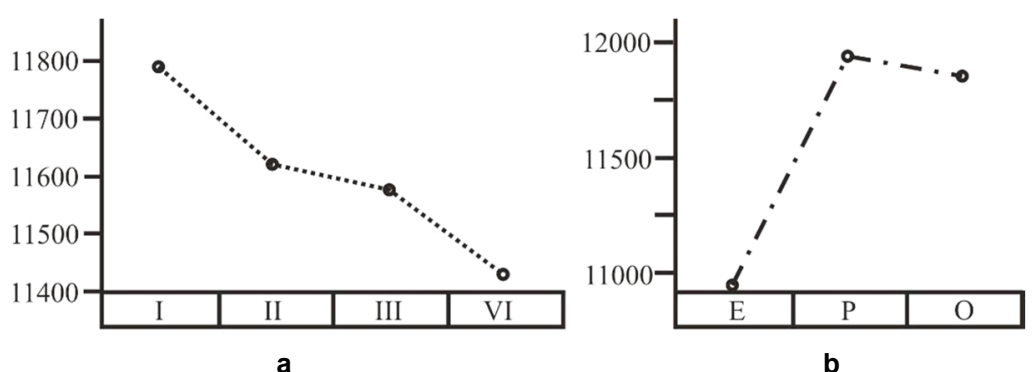

Fig. 3. Variability of the hardness of quartz from productive strata of deposit:

$a$ - quartz from unaltered ferruginous quartzites; $b$ - quartz from sodium metasomatites; $11000-12000$ - average value of the hardness

Mineral varieties of ferruginous quartzites: see Fig. 1. Zone of sodium metasomatites: see Fig. 1

From this perspective, the author investigated the variability of contents of impurity elements in quartz from various mineral zones of the productive strata of the deposit using the method of quantitative spectral analysis. The minimum size of mechanical inclusions in crystals of quartz, taking into account the results of microscopic studies, was determined to be $0,001 \mathrm{~mm}$. Quartz-containing ferruginous

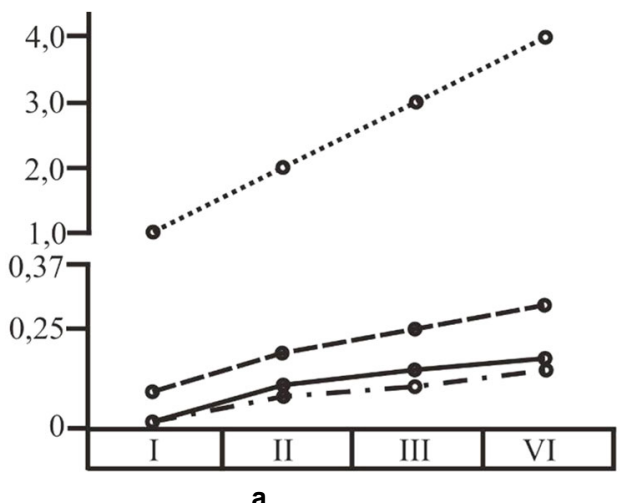

\section{…... 1 E- 2 E. 4} provided almost complete release of quartz attachments to magnetite, micaceous hematite, silicates, carbonates. Using the methods of magnetic and gravitational beneficiation, monomineral fractions of quartz were obtained. The latter were subjected to semi-quantitative spectral analyzes. The results are shown in Fig. 4 (Table 7-8).

Fig. 4. Variability of the average content $(0-0,4)$ of the admixture elements

in quartz from unaltered ferruginous quartzites (a) and from sodium metasomatites (b)

$$
1-\mathrm{Cu} ; 2-\mathrm{Mn} ; 3-\mathrm{Zn} ; 4-\mathrm{Pb} \text {. }
$$

Mineral varieties of ferruginous quartzites: see Fig. 1. Zone of sodium metasomatites: see Fig. 1

Table 7

The intermedial content of the admixture elements in quartz from unaltered ferruginous quartzites of the productive strata

\begin{tabular}{|c|c|c|c|c|c|c|c|c|c|c|c|c|}
\hline \multirow{2}{*}{ № } & \multirow{2}{*}{ Mineral varieties } & \multirow{2}{*}{$\mathbf{n}$} & \multicolumn{10}{|c|}{ Content of the admixture elements } \\
\hline & & & $\mathbf{A l}$ & $\mathrm{Fe}$ & Mn & Mg & $\mathrm{Ca}$ & $\mathrm{Na}$ & $\mathrm{K}$ & $\mathrm{Cu}$ & $\mathrm{Pb}$ & $\mathrm{Zn}$ \\
\hline 1 & $\begin{array}{l}\text { Micaceous-hematite- } \\
\text { magnetite quartzites }\end{array}$ & 3 & 0,0178 & 0,1127 & 0,00007 & 0,0058 & 0,00047 & 0,0074 & 0,00114 & 0,00102 & 0,00004 & 0,00004 \\
\hline 2 & Magnetite quartzites & 5 & 0,0203 & 0,0831 & 0,00019 & 0,0115 & 0,00064 & 0,0035 & 0,00132 & 0,00201 & 0,00006 & 0,00009 \\
\hline 3 & $\begin{array}{l}\text { Cummingtonite-magnetite } \\
\text { quartzites }\end{array}$ & 4 & 0,0328 & 0,0586 & 0,00025 & 0,0249 & 0,00097 & 0,0021 & 0,00147 & 0,00306 & 0,00008 & 0,00011 \\
\hline
\end{tabular}

Note: $n$ - number of determinations (analysed samples).

The content of elements ( $\mathrm{V}, \mathrm{Bi}, \mathrm{Ga}, \mathrm{Co}$, e. a.) was also studied, but their presence was not detected.

Table 8

The intermedial content of the admixture elements in quartz from from sodium metasomatites, which were formed in

\begin{tabular}{|c|c|c|c|c|c|c|c|c|c|c|c|c|}
\hline \multirow{2}{*}{ № } & \multirow{2}{*}{ Mineral varieties } & \multirow{2}{*}{$\mathbf{n}$} & \multicolumn{10}{|c|}{ Content of the admixture elements } \\
\hline & & & $\mathbf{A l}$ & Fe & Mn & $\mathrm{Mg}$ & $\mathbf{C a}$ & $\mathrm{Na}$ & $\mathbf{K}$ & $\mathrm{Cu}$ & $\mathbf{P b}$ & $\mathrm{Zn}$ \\
\hline \multicolumn{13}{|c|}{ micaceous-hematite-magnetite quartzites } \\
\hline 1 & $\begin{array}{l}\text { Riebeckite- magnetite-aegirine } \\
\text { metasomatites }\end{array}$ & 6 & 0,0503 & 0,0382 & 0,00007 & 0,0108 & 0,00123 & 0,0237 & 0,00742 & 0,00138 & 0,00011 & 0,00007 \\
\hline 2 & $\begin{array}{l}\text { Micaceous-hematite-riebeckite- } \\
\text { magnetite quartzites }\end{array}$ & 3 & 0,0223 & 0,0403 & 0,00010 & 0,0102 & 0,00082 & 0,0324 & 0,00578 & 0,00102 & 0,00007 & 0,00004 \\
\hline 3 & $\begin{array}{l}\text { Micaceous-hematite-magnetite } \\
\text { quartzites silificate }\end{array}$ & 4 & 0,0218 & 0,0423 & 0,00013 & 0,0100 & 0,00061 & 0,0098 & 0,00234 & 0,0064 & 0,00004 & 0,00002 \\
\hline \multicolumn{13}{|c|}{ magnetite quartzites } \\
\hline 5 & $\begin{array}{l}\text { Riebeckite-magnetite-aegirine } \\
\text { metasomatites }\end{array}$ & 6 & 0,0503 & 0,0382 & 0,00013 & 0,0108 & 0,00123 & 0,0237 & 0,00742 & 0,00138 & 0,00011 & 0,00011 \\
\hline 6 & Riebeckite-magnetite quartzites & 5 & 0,0274 & 0,0274 & 0,00016 & 0,0197 & 0,00128 & 0,0273 & 0,00321 & 0,00103 & 0,00007 & 0,00009 \\
\hline 7 & Magnetite quartzites silificate & 4 & 0,0238 & 0,0323 & 0,00024 & 0,0246 & 0,00304 & 0,0115 & 0,00236 & 0,00083 & 0,00007 & 0,00007 \\
\hline
\end{tabular}


Variability of the content of $\mathrm{Al}, \mathrm{Mg}, \mathrm{Fe}, \mathrm{Ca}, \mathrm{Na}, \mathrm{K}$ in Fig. 4 are not shown, because their presence in the quartz was due to the presence of very small (up to $0,01 \mathrm{~mm}$ ) inclusions of magnetite, micaceous hematite, silicates and carbonates.

The data obtained show the content of all elements $(\mathrm{Cu}$, $\mathrm{Mn}, \mathrm{Zn}, \mathrm{Pb}$ ) in quartz from the ferruginous quartzites to increase significantly from the central zones of micaceous hematite-magnetite of the fifth ferruginous horizon to peripheral cummingtonite-magnetite ones. This is supposed to be due to the peculiarities of the chemical composition of the enclosing rocks. As a result, the possibility of their entering into a crystalline lattice of quartz or into the smallest mechanical mineral inclusions in its crystals and aggregates increases.

Variations in the content of impurity elements in quartz from sodium metasomatites are characterized by more complicated regularities. The number of chalcophylic elements $(\mathrm{Cu}, \mathrm{Zn}, \mathrm{Pb})$ significantly decreases in the direction from the central zones of aegirinization to the peripheral zones of silicification. In the author's opinion, this is explained by the inwash of these elements by metasomatizing solutions and their maximum deposition in the immediate vicinity of the supply channels. The content of $\mathrm{Mn}$ in the indicated direction increases. Perhaps, this is due to its low activity in the metasomatizing solution and, consequently to its transition from the original rock to the solution in the process of metasomatosis.

Conclusions. The productive strata of the Northern region of the Kryvyi Rih basin is characterized by the manifestation of various geological processes such as sedimentation, diagenesis, tectonogenesis, metasomatosis and others. The manifestation of the autogenicmetamorphogenic zonation within the productive strata of the Pervomayske and Hannivka deposits determines the variability of both physical and chemical properties of the main rock-forming minerals of ferruginous quartzites.

The microhardness of magnetite and quartz naturally decreases in sections of metamorphic deposits of magnetite ores. This index for magnetite from metasomatic zones is gradually increasing, which is due to the improvement in the process of metasomatic changes in the internal structure of its individuals. The maximum microhardness of quartz is typical for the riebeckitization zones. The minimum hardness is characteristic of quartz from the zones of aegirinization.

The value of microhardness of minerals can be used as a mineralogical property of magnetite quartzites of different geological locations and different genesis.

The variability of the chemical composition of magnetite varies depending on the manifestation of the geological processes (syngenetic and epigenetic) and the position of the main ore mineral in the section of the productive strata. The influence of the content of the enclosing rocks is noticeable when comparing the contents of $\mathrm{Al}_{2} \mathrm{O}_{3}, \mathrm{MgO}$, $\mathrm{MnO}, \mathrm{CaO}, \mathrm{K}_{2} \mathrm{O}$ in magnetite from metasomatically altered micaceous hematite - magnetite and magnetite quartzites.

Variations in the content of impurities in quartz from sodium metasomatites are characterized by more complicated laws, compared with the composition of quartz from unaltered ferruginous quartzites. The number of chalcophylic elements decreases from the zones of aegirinization to the zones of silicification due to the inwash of these elements by metasomatizing solutions and their maximum deposition in the immediate proximity to the supply channels.

The results of the variation of the chemical composition and physical properties of the main rock-forming minerals in the sections of deposits of ores of various origins must be taken into account in the practical work of the geological and technological services of the Northern Ore Mining and Beneficiating Works.

\section{Список використаних джерел}

Белевцев, Р.Я. (1970). Метаморфическая зональность Криворожского бассейна. Геологический журнал, 30, 4, 25-38.

Белик, Д.М., Кутин, В.В., Решетняк, В.В. (1984). Зональность разнопорядковых елементов криворожской железорудной свиты. Изв. АН СССР. Сер. Геол., 2, 79-85.

Беспояско, Е.О. (2004). Вплив мінерального складу на фізичні та технічні властивості вивітрених залізистих порід Інгулецького родовища (Криворізький басейн). Геолого-мінералогічний вісник Криворізького технічного університету, 1, 40-47.

Глазунов, С.Н. (2005). "Северный горно-обогатительный комбинат" на пути динамического развития. Горный журнал, 5, 27-29.

Евтехов, В.Д. (1992). Генетическая и прикладная минералогия натриевых метасоматитов железисто-кремнистых формаций Украинского щита (по природным и экспериментальным данным). Автореф. дис. д-ра геол.-минералог. наук: 04.00.20. Львов.

Евтехов, В Д. Доценко, В Д (1979). О магнитных свойствах магнетита Первомайского месторождения Кривбасса. Материалы научно-технической конференции Криворожского горнорудного института. Секция геолого-минералогическая. Кривой Рог, 46-53.

Євтєхов, В.Д., Карпенко, С.В., Євтєхова, А.В. (2009). Топомінералогія саксаганської світи Ганнівського родовища Криворізького басейну. Записки Українського мінералогічного товариства, 6, 77-84

Карпенко, С.В., Евтехов,, В.Д., Евтехова, А.В. (2009). Аутигенно-метаморфогенная минералого-геохимическая зональность продуктивной толщи Анновского месторождения (Криворожский бассейн). Науковий вісник НГУ, 3, 54-57.

Карпенко, С.В., Евтехов,В.Д. (2006). Соотношение значений общего содержания железа и содержанияе го растворимых форм в рудах Анновского месторождения (Криворожский бассейн). Геолого-мінералогічний вісник. 2 (16), 92-95.

Матковський, О., Павлишин, В., Сливко, Е. (2009). Основи мінералогії України. Львів: Видавничий центр ЛНУ ім. Івана Франка.

Павлишин, В.И. (1984). Генетические и прикладные аспекты учения о типоморфизме минералов. Минералогический журнал, 5, 16-23.

Павлишин, В.І., Матковький, О.І., Довгий, С.О. (2003). Генезис мінералів. Київ.: Видавничо-поліграфічний центр "Київський університет".

Паранько, І.С. (1997). Формації і стратиграфрія Криворізької структури. Відомості академії гірничих наук України, 4, 54-58.

Ракович, Ф.И. (1983). Типоморфные свойства магнетитов из железисто-кремнистых пород и богатых руд УЩ как показатель условий образования. Геологический журнал, 43, 5, 87-92.

Тіхлівець, С.В. Філенко, В.В. (2018). Морфологічні особливості магнетиту продуктивної товщі Північного району Криворізького басейну. Мінералогічний збірник, 68, 58-61.

Чубаров, В.А., Евтехов, В.Д. (1996). Индефикация минеральных разновидностей и технологических сортов руд Кривбасса. Горный журнал, $11-12,14-17$.

Karpenko, S. (2008). Mineralogical zone of ferruginous horizons of Kryvyi Rih Annovskoye deposit. Збірка тез всеукраїнської науково-практичної конферениії, Кривий Рі2,128-129.

Prušinskienè, S., Šiliauskas, L., Skridlaitè, G. (2017). Varieties and chemical composition of magnetite in the Varèna Iron Ore Deposit. Chemija, 28 (1), 39-57.

Tikhlivets, S. (2017). Mineral composition of zones of contact of dikes of granite and rocks of iron-siliceous formation of the Krivoy Rog Basin. Proceedings of the International Scientific Conference. "International Trends in Science and Technology", October 17, 2017, Warsaw, Poland, 4-7.

Tikhlivets, S., Filenko, V. (2017). Mineralogy of sodium metasomatites of the Pervomayske deposit and their influence on quality of iron ore concentrate. Вісник Київського національного університету імені Тараса Шевченко. Геологія, 4 (79), 53-58.

Tikhlivets, S.V. (2019). Morphological features of magnetite and quartz from productive series of the Kryvyi Rih basin Northen region. Вісник Київського національного університету імені Тараса Шевченко. Геологія, 2 (85), 28-36. http://doi.org/10.17721/1728-2713.85.04

\section{References}

Belevtsev, R.Ya. (1970). Metamorphic zoning of the Krivoy Rog basin. Geological Journal, 30, 4, 25-38. [in Ukranian]

Belik, D.M., Kutin, V.V., Reshetnyak, V.V. (1984). Zonality of different elements of the Krivoi Rog iron-ore suite. News of the USSR Academy of Sciences. Ser. geol., 2, 79-85. [in Russian]

Bespoyasko, E.O. (2004). Effect of mineral composition on the physical and technical properties of weathered ferruginous rocks of the Ingulets deposit (Kryvy Rih basin). Geological and Mineralogical Bulletin of Kryvyi Rih Technical University, 1, 40-47. [in Ukranian]

Glazunov, S.N. (2005). OJSC Northern Mining and Processing Plant on the path of dynamic development. Mining Journal, 5, 27-29. [in Russian]

Evtekhov, V.D. (1992). Genetic and applied mineralogy of sodium metasomatites in the ferruginous-siliceous formations of the Ukrainian shield (according to natural and experimental data). Extended abstract of Doctor's thesis (Mineralogy, Crystallography): 04.00.20. Lviv. [in Russian]

Evtekhov, V.D., Dotsenko, V.D. (1979). On the magnetic properties of the magnetite of the Pervomaisky deposit of Krivbass. Proceedings of the 
scientific and technical conference of the Krivoy Rog Mining Institute. Geological and mineralogical section. Krivoy Rog, 46-53. [in Russian]

Karpenko, S.V., Evtekhov, V.D. (2006). The ratio of the total iron content and the content of its soluble forms in the ores of the Annovskoye deposit (Krivoy Rog basin). Geological and Mineralogical Bulletin of Kryvyi Rih Technical University, 2 (16), 92-95. [in Russian]

Evtekhov, V.D., Karpenko, S.V., Yevtyekhova, A.V. (2009). Topomineralogy of the Saksagan series of the Gannivsky deposit of the Kryvy Rih basin. Notes from the Ukrainian Mineralogical Society, 6, 77-84. [in Ukranian]

Karpenko, S. (2008). Mineralogical zone of ferruginous horizons of Kryvyi Rih Annovskoye deposit. Collection of abstracts of the All-Ukrainian scientificpractical conference. Kryviy Rih, 128-129.

Karpenko, S.V. Evtekhov, V.D., Evtekhova, A.V. (2009). Authigenicmetamorphogenic mineralogical and geochemical zoning of the productive stratum of the Annovskoye field (Krivoy Rog basin). Scientific bulletin of NMU, 3, 54-57. [in Russian]

Matkovsky, O., Pavlyshyn, V., Slyvko, E. (2009). Fundamentals of Mineralogy of Ukraine. Lviv: Publishing Center of LNU them. Ivan Franko. [in Ukranian]

Pavlishin, V.I., Matkovskiy, O.I., Dovgiy, S.O. (2003). Genesis of minerals. Kyiv. [in Ukranian]

Pavlishin, V.I. (1984). Genetic and applied aspects of study about tipomorphism of minerals. Mineralogical journal, 5, 16-23. [in Russian]

Paranko, I.S. (1997). Formations and stratigraphy of the Krivoy Rog structure. Information from the Academy of Mining Sciences of Ukraine, 4, 54-58. [in Ukranian]

С. Тіхлівець, канд. геол. наук., доц.,

E-mail: tikhlivets.svetlana@gmail.com;

Криворізький національний університет,

вул. Пушкіна, 37, м. Кривий Ріг, 50002, Україна
Rakovich, F.I. (1983). Typomorphic properties of magnetites from ferroussiliceous rocks and rich ores USH as an indicator of the conditions of education. Geological journal, 43, 5, 87-92. [in Russian]

Prušinskienè, S., Šiliauskas, L., Skridlaitè, G. (2017). Varieties and chemical composition of magnetite in the Varèna Iron Ore Deposit. Chemija, 28 (1), 39-57.

Tikhlivets, S. (2017). Mineral composition of zones of contact of dikes of granite and rocks of iron-siliceous formation of the Krivoy Rog Basin. Proceedings of the International Scientific Conference. "International Trends in Science and Technology". October 17, 2017, Warsaw, Poland, 4-7.

Tikhlivets, S., Filenko, V. (2017). Mineralogy of sodium metasomatites of the Pervomayske deposit and their influence on quality of iron ore concentrate. Visnyk of Taras Shevchenko National University of Kyiv. Geology, 4 (79), 53-58.

Tikhlivets, S.V., Filenko, V.V. (2018). Morphological features of magnetite from productive series of the Kryvyi Rih basin Northen region. Mineralogical collection, 68, 58-61. [in Ukranian]

Tikhlivets, S.V. (2019). Morphological features of magnetite and qaurt from productive series of the Kryvyi Rih basin Northen region. Visnyk of Taras Shevchenko National University of Kyiv: Geology, 2 (85), 28-36. http://doi.org/10.17721/1728-2713.85.04

Chubarov, V.A., Evtekhov, V.D. (1996). Identification of mineral varieties and technological ore grades of Krivbass. Mining Journal, 11-12, 14-17 [in Russian] Надійшла до редакції 04.06.2020

\section{ВАРІАТИВНІСТЬ ФІЗИЧНИХ І ХІМІЧНИХ ВЛАСТИВОСТЕЙ МАГНЕТИТУ ТА КВАРЦУ ПІВНІЧНОГО РАЙОНУ КРИВОРІЗЬКОГО БАСЕЙНУ}

Фізичні властивості мінералів є функцією їхнього хімічного складу, особливостей морфології й анатомії. На їхню варіативність впливають геологічні сингенетичні й епігенетичні процеси, які виявлені в межах залізорудних родовищ Криворізького басейну. Останній представлений дев'ятьма родовищами, які розробляються п'ятьма гірничозбагачувальними комбінатами. У Північному районі Криворізького басейну розташовані Ганнівське і Первомайське родовища. Продуктивна товща обох родовища представлена бідними магнетитовими рудами п'ятого і шостого залізистих горизонтів, для яких характерний прояв аутигенно-метаморфогенної мінералогічної зональності.

Мета роботи обумовлена необхідністю детального вивчення закономірностей варіативності хімічного складу і фізичних властивостей породотвірних мінералів (магнетит і кварц) з урахуванням їхньої позиції в межах зональних рудних покладів.

Вивчення фізичних властивостей породотвірних мінералів проводилося за стандартними методиками з використанням мікротвердоміру, хімічних склад досліджувався шляхом виділення мономінеральних фракцій магнетиту і кварцу з різних за мінеральним складом руд метаморфічного і метасоматичного походження за допомогою магнітного сепаратора. Хімічні аналізи проводились у стандартизованій хімічній лабораторії. Cтатистичні дослідження виконувалися за допомогою комп'ютерних програм Exсеl та Corel Draw.

Наукова новизна. У результаті проведених досліджень виявлено характер варіативності хімічного складу, фізичних властивостей магнетиту та квариу в розрізах метаморфогенних і метасоматично зміненних рудних покладів залізорудних родовищ.

Практична значимість обумовлена необхідністю проведення, на основі вивчення фізико-хімічних властивостей головних породотвірних мінералів залізистих кварцитів, детального топомінералогічного дослідження продуктивної товщі залізорудних родовищ Криворізького басейну у зв'язку з проведенням робіт щодо уточнення мінералого-технологічної карти родовища, складання оптимальної схеми усереднення руд з метою підвищення ефективності використання природного технологічного потенціалу магнетитових кварцитів.

Ключові слова: Український щит, залізисто-кремниста формація, Криворізький басейн, залізисті кварцити, магнетит, кварц.

С. Тихливец, канд. геол. наук., доц.,

E-mail: tikhlivets.svetlana@gmail.com;

Криворожский национальний университет,

ул. Пушкина, 37, г. Кривой Рог, 50002, Украина

\section{ВАРИАТИВНОСТЬ ФИЗИЧЕСКИХ И ХИМИЧЕСКИХ СВОЙСТВ МАГНЕТИТА И КВАРЦА СЕВЕРНОГО РАЙОНА КРИВОРОЖСКОГО БАССЕЙНА}

Физические свойства минералов являются функцией их химического состава, особенностей морфологии и анатомии. На их вариативность влияют геологические сингенетические и эпигенетические процессы, которые проявлены в пределах железорудных месторождений Криворожского бассейна. Последний представлен девятью месторождениями, которые разрабатываются пятью горнообогатительными комбинатами. В Севереном районе Криворожского бассена находятся Анновское и Первомайское месторождения. Продуктивная толща обоих месторождений представлена бедными манетитовыми рудами пятого и шестого железистих горизонтов, для которых характерно проявление аутигенно-метаморфогенной минералогической зональности.

Цель работы обусловлена необходимостью детального изучения закономерностей вариативности химического состава и физических свойств породообразующих минералов (магнетит и кварц) с учетом их позиции в пределах зональных рудных залежей.

Изучение физических свойств минералов проводилось по стандартным методикам с использованием микротвердомера, химический состав исследовался путем выделения мономинеральных фракций магнетита и кварца из разных по минеральному составу руд метаморфического и метасоматического происхождения с помощью магнитного сепаратора. Химические анализы проводились в стандартизированной химической лаборатории. Cтатистические исследования выполнялись с помощью компьютерных программ Ехсеl и Соrеl Draw.

В результате проведенных исследований определен характер вариативности химического состава, физических свойств магнетита и кварца в разрезах метаморфогенных и метасоматически измененных рудных залежей железорудных месторождений.

Практическая значимость обусловлена необходимостью проведения, на основе изучения физико-химических свойств главных породообразующих минералов железистых кварцитов, детального топоминералогического исследования продуктивной толщи месторождений Криворожского бассейна в связи с проведением работ по уточнению их минералого-технологических карт, составлению оптимальных схем усреднения руд с целью повышения эффективности использования природного технологического потенциала магнетитовых кварцитов.

Ключевые слова: Украинский щит, железисто-кремнистая формация, Криворожский бассейн, железистые кварциты, магнетит, кварц. 